\title{
Feeling and Form in Mark Bradford's American Pavilion
}

\section{Introduction}

Mark Bradford's Tomorrow is Another Day exhibition for the American Pavilion at the Venice Biennale 2017 immediately confronted viewers with an enormous sculpture entitled Spoiled Foot (2016, fig. 1). After entering the Pavilion by a side door rather than the central portico, visitors were compelled to squeeze around the edges of this tactile, monstrous lump which seemed to emerge from the ceiling. Made up of hundreds of posters tacked together, peeling off and distressed at their edges, Spoiled Foot is predominantly black, also containing stretches of pale blue, white, crimson, orange and pink, repeatedly studded with orange tacks. Its shape and texture is reminiscent of a 'fatberg': those huge subterranean objects occupying London's aging sewers. Composed of fat, sanitary towels, baby wipes, condoms, nappies and similar non-compostable items found in sewer systems, these monsters of human detritus have become a recent topic of fascination in the British press. ${ }^{1}$ Though built up by posters rather than sanitary items and thus taking on a more colourful and far less grotesque hue, the resonance with the fatberg lies in the buried, yet eruptive aspect that I will argue is central to how Bradford's work engages with histories of modernism.

In the next room of the Pavilion, another seemingly putrefying, formless, yellow and black sculpture entitled Medusa (fig. 2) occupied the centre of the room, surrounded by a contrasting suite of serene purple, violet, and black gridded works named after sirens: Thelxiepeia, Leucosia and Raidne (2016) (figs. 2-4). The dynamic between integration and wholeness, as well as disintegration and wreckage continued throughout the exhibition, oscillating between the black and yellow tentacles of Oracle (2017, fig. 5), which appear to overrun the central room over the Pavilion, and the lyrical abstraction of 105194 (2016, fig. 6). Before exiting, a short video entitled $\mathrm{Ni}$ agara (2015, fig. 6) showed Bradford's then neighbour, a young black man named Melvin, walking down the street in Los Angeles. Dressed in a white vest, yellow baseball shorts, white socks pulled high and black sneakers, Melvin treads a path studded with litter and the same posteradvertisements that compose Bradford's works, from the visible stretches of Spoiled Foot to the more tangible use of these in earlier works such as his Merchant Posters series. Rather than marketing aspirational commodities, the advertisements Bradford works with sell credit, paternity tests, bedbug removal, immigration advice, legal services, and predatory house-purchase schemes (fig. 7).

In Niagara, the perspective of the camera exacerbates the incline of the hill Melvin walks down, and he eventually strolls out of sight. His yellow shorts match the posters and discarded cups littering the street, and he swings his arms, walking with an ambling pleasure that solidifies the reference made by the work's title - Niagara to the 1953 film noir starring Marilyn Monroe. Niagara is a film now best known for Monroe's sashaying out of sight, the longest walk-away captured on camera at the point of its release. Melvin's walk is thus an image of Los Angeles as the creation ground for cinema's myths, as much as it is a representation of contemporary urban neglect, rendered in the litter, cracked paving slabs and posters decorating his path. This tension between fantasy and dispossession was pulled taut through Bradford's Pavilion, moving from modernist grids and expressionist skeins to referencing the social world in which 
these works are made. Bradford's work therefore presents a means to rethink the social currencies of art along lines that exceed the split between realism and abstraction that originated within the inter-war avant-gardes, and has continued to shape critical theories of art.

A crucial debate in establishing this cleavage took place in the 1930s, when Ernst Bloch clashed with Georg Lukács over the meaning of expressionism, with their discussion centred on how artistic form could contest, or indeed support the growth of fascism and the devastations wreaked by capitalism. In 1934, Lukács wrote that expressionism is marked by an "extraordinary poverty of content [which] stands in crying contrast to the pretension of its delivery, to the exaggerated and over-intense subjective emotionalism of its presentation." ${ }^{2}$ For Lukács, the failings of German expressionism partly lay in its bohemianism, its drive to mark itself out as an alternative to bourgeois life, while all the time accommodating and feeding the world it claims to step away from, in its move from the battlefield of class struggle towards the "private realm of morality". ${ }^{3}$ Lukács situated expressionism as the aesthetic form paralleling Lebensphilosophie in philosophy, and viewed these movements as politically cogent with the anti-war, reformist ideology of the Independent Social Democratic Party of Germany (USPD). Writing in 1934 and looking back on the immediately preceding period, Lukács positioned all three - expressionism, Lebensphilosophie and the USPD - as symptoms of German imperialism, which in his analysis formed the bedrock of fascism. While he did not accuse expressionism of being inherently fascistic and acknowledged its uneven place for the National Socialists, Lukács wrote that its proponents "shared uncritically and without resistance in the ideological decay of the imperialist bourgeoisie" meaning "their creative method needed no distortion to be pressed into the service of fascist demagogy, of the unity of decadence and regression". ${ }^{4}$
Following the renewal of a debate on expressionism within communist circles after the initiation of the Popular Front in 1935, Bloch entered into the fray in $1938 .^{5}$ He stressed that Lukács had largely relied on postscripts, introductions and newspaper articles, but skirted around painting, music and most expressionist poetry in building his 1934 argument. Through this, Bloch contended that Lukács's analysis "produces only a concept of concepts, an essay on essays and even lesser pieces", 6 adding up to a polemic that relied on the mechanistic concept of reflection employed in dialectical materialism. In large part, their disagreement revolved around the question of cultural heritage, with Bloch's interest in expressionism partly resting upon the way it moved beyond the classical Western paradigm and instead drew on a diverse range of sources including folk culture, primitivism, non-Western art and art made by the mentally ill. ${ }^{8}$ For Bloch, expressionism's recourse to other traditions and cultures resonated with his concept of history as a multi-temporal dialectic, the means by which he had analysed the growth of fascism in 1932. Through Bloch's theory of nonsynchronous contradictions, he examined the uneven experiences and responses to capitalist development and rationalisation, distinguishing between their objective and subjective form. Objective non-synchronous contradictions were the actual existence of older forms of life, modes of production and belief systems that contradicted present-day, capitalist society while subjective non-synchronous contradictions described the response to this - 'accumulated rage' - fantasies of a lost social wholeness that supported the growth of fascism. ${ }^{9}$ But as Bloch also stressed, there was another form of non-synchrony that sought to deliver a "subversive-utopian [...] life which never received fulfilment in any age". ${ }^{10}$ This romantic anti-capitalism, which guided Bloch's analysis of expressionism, was criticised by Lukács, who saw it as rendering cultural heritage into "a heap of lifeless objects in which one 


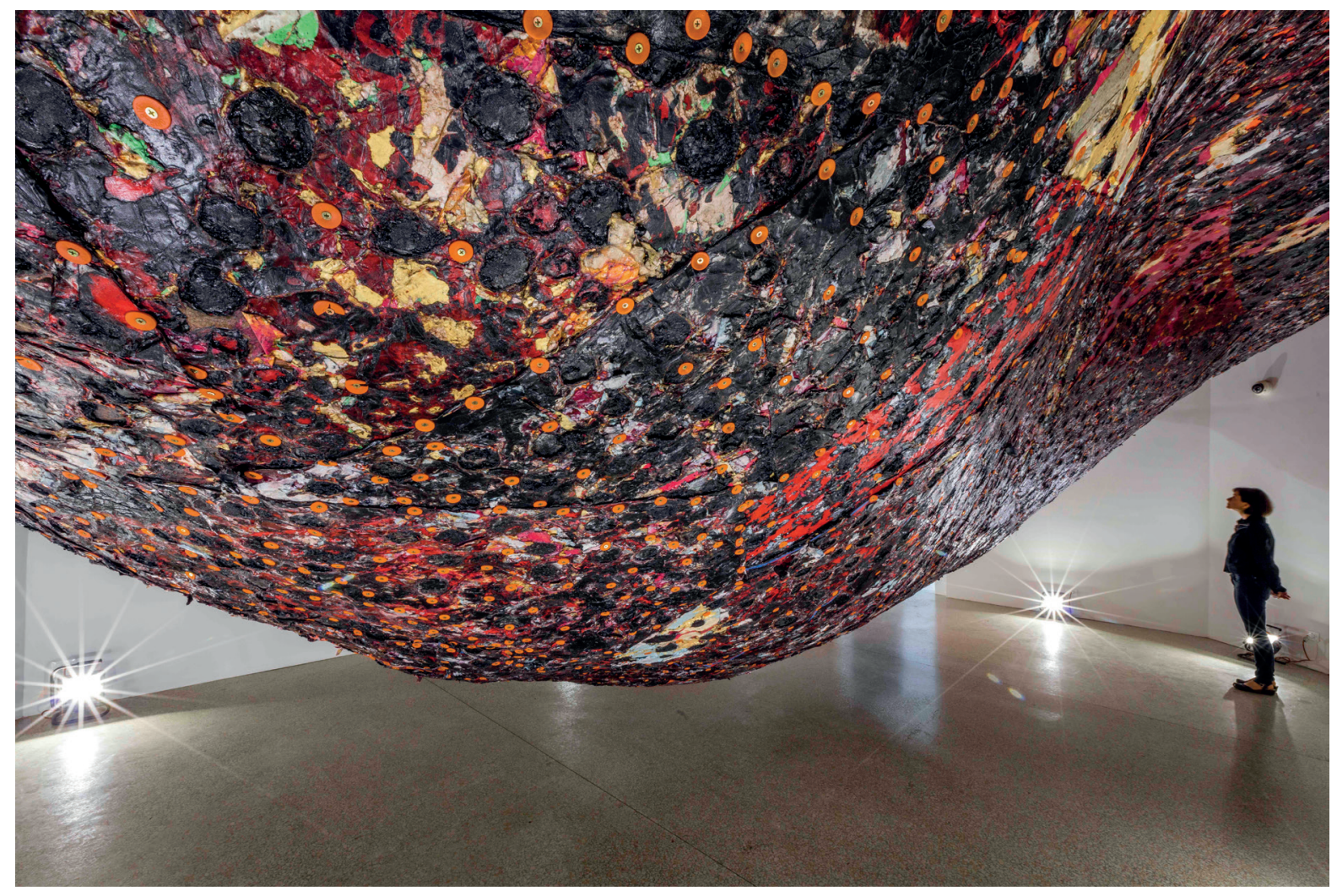

1 Installation view of Mark Bradford, Spoiled Foot (detail), 2016, mixed media on canvas, lumber, luan sheeting, and drywall, dimensions variable, part of: Mark Bradford, Tomorrow Is Another Day. Venice, Biennale 2017, U.S. Pavilion

can rummage around at will [...] in accordance with the exigencies of the moment". ${ }^{11}$

For Lukács, expressionism left the fate of realism hanging in the balance. Where expressionism was abstract, irrational and subjective, realism was capable of penetrating "the laws governing objective reality" and uncovering "the deeper, hidden, mediated, not immediately perceptible network of relationships that go to make up society". ${ }^{22}$ Conversely, for Bloch, it was precisely expressionism's recourse to the emotive, the irrational, to montage and abstraction that was most capable of exploiting "the real fissures in surface inter-relations and to discover the new in their crevices" ${ }^{13}$ Far more than being only a quibble about expressionism, their split rested upon a disagreement about totality. For Lukács, the reality of capitalism produced a coherent totality, which realism could de-reify, whereas for
Bloch, reality was discontinuous, with the spread of capitalism producing multiple non-synchronous contradictions that forms such as montage could articulate. ${ }^{14}$

While rehearsing this almost century-old debate may seem an unlikely way to begin an essay on a contemporary artist, it assists in showing how Bradford's work in the American Pavilion holds a number of the strategies Bloch and Lukács debated in tension: expressionist feeling and abstract form as well as realist representations of social relations. In its mixing of these forms and registers, Bradford's American Pavilion thus reveals, once again, the fallaciousness of cleaving the social from abstraction, something the artist has sought to override in describing his practice as "social abstraction", a term summarised by Bradford as "abstract art with a social or political context clinging to the edges". ${ }^{15}$ As 


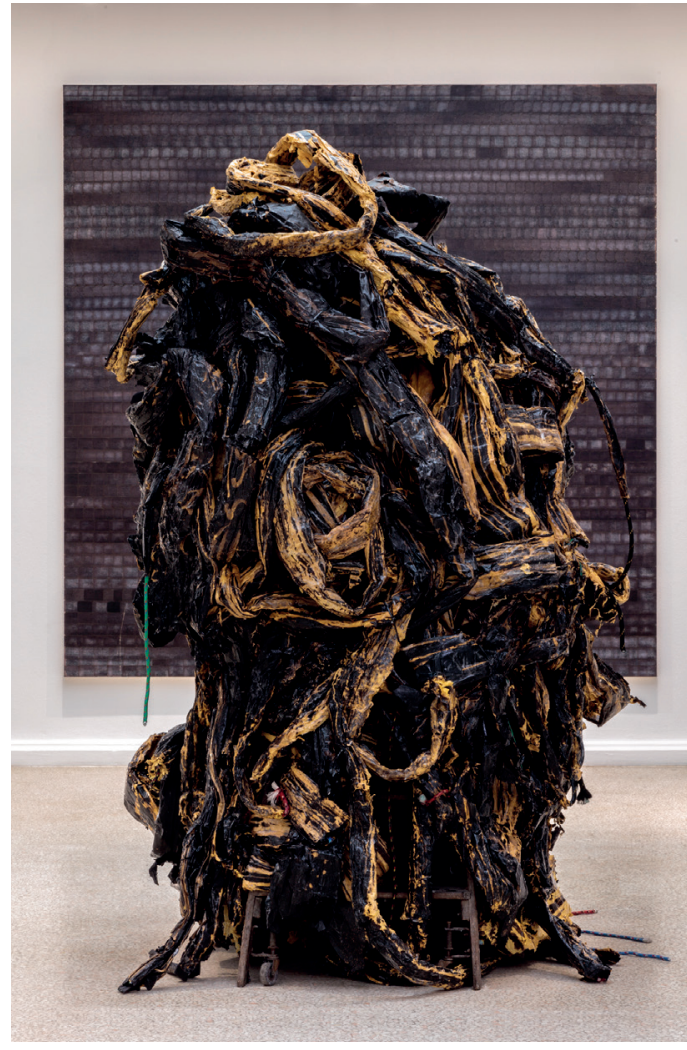

2 Installation view of Mark Bradford, Tomorrow Is Another Day. Venice, Biennale 2017, U.S. Pavilion In the foreground: Medusa, 2016, acrylic paint, paper, rope, caulk, dimensions variable; in the background: Raidne, 2016, mixed media on canvas, $304.8 \times 304.8 \mathrm{~cm}$

already suggested, Bradford's American Pavilion oscillates between integration and disintegration, wreckage and repair, totality and fracture. Through exploring this dynamic more closely, I want to suggest that the split between realism and abstraction too often leaves the violence at the heart of the modern enlightenment project - which in fact binds these two categories unquestioned. In order to do this, I draw on scholarship from the field of black studies, which assists in rethinking those central debates from the 1930 and how they might bear on Bradford's social abstraction as working through the legacies of high abstraction and expressionism, during a period where we have seen the steady growth of fascism and nationalism.

\section{Social Abstraction, or Fungibility and the Grid}

Bradford's category of 'social abstraction' is called up through his titling of works, which since at least the early 2000 s suggestively weave a tapestry of references. In a breakthrough review by Holland Cotter from 2001, the critic recognises Bradford's On a Clear Day I Can Usually See All the Way to Watts (2001) as a reference to Agnes Martin's On a Clear Day print series (1973). ${ }^{16}$ As Bradford explains, such references partly function as "sugar cubes for curators", leaving a trail that integrates his work within a modernist lineage, whilst also emphasising the social through the reference to Watts, a poor African American neighbourhood in Los Angeles which remains best known for the 1965 uprising. ${ }^{17}$

The 'social' in Bradford's social abstraction is also rendered through his choice of materials, with his major artistic development coming when he started to use hairdressers' endpapers in his work. A third-generation hairdresser, Bradford worked at his mother's salon in South Central Los Angeles for many years, before alighting on the possibility of using permanent wave endpapers as a material in his artwork; these are rectangular, tissue-thin strips of paper that are used to wrap curls when doing a permanent wave. Their transparent and flimsy quality led Bradford to experiment with using hair dye on the surface and burning the edges, before gridding the endpapers onto the canvas. In part an economic choice because of their cheapness, Bradford also remarks that he began using the permanent endpapers for their capacity to denote a social fabric, a reasoning that also guides his use of posters, pulled off billboards in low-income, black neighbourhoods in South Central Los Angeles. In both the endpaper and poster works, Bradford 


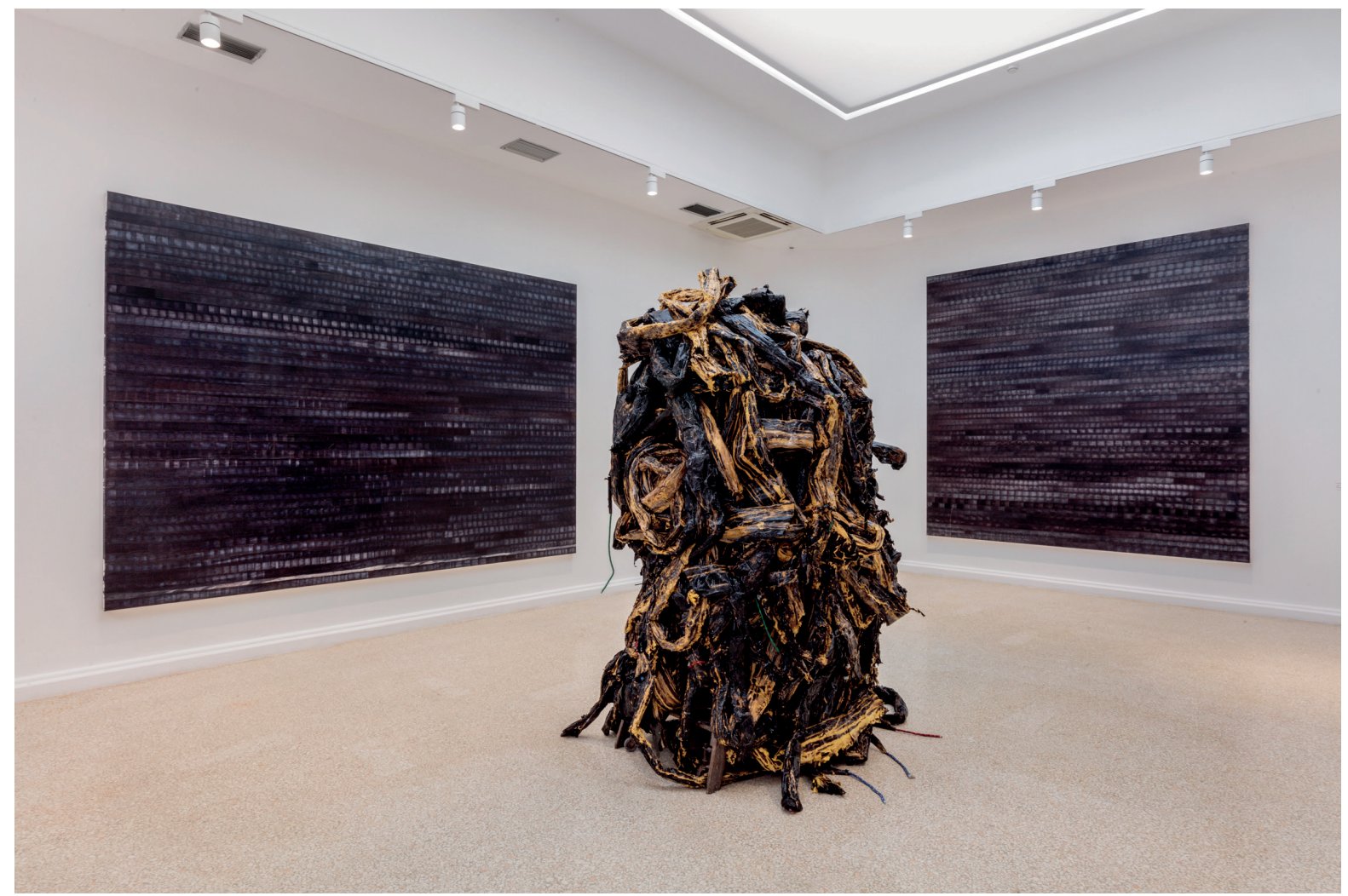

3 Installation view of Mark Bradford, Tomorrow Is Another Day. Venice, Biennale 2017, U.S. Pavilion Left to right: Leucosia, 2016, mixed media on canvas, $259.1 \times 365.8 \mathrm{~cm}$; Medusa (cf. fig. 2); Raidne (cf. fig. 2)

tends to finish the canvas by using a sander to smooth out and reveal the palimpsest-like layers. He describes this finishing process as akin to combing out a client's hair after a wave, dye or other treatment has been given. ${ }^{18}$

In the siren suite displayed in the American Pavilion, Raidne (2017), Leucosia (2016), and Thelxiepeia (2016), all mark a return to Bradford's use of the endpapers for the first time in thirteen years. Of different sizes and shapes, these three canvases share the same gridded appearance through the rows of endpapers, which have been coated in dye ranging from inky black tones through to purple-reddish tones and blueish-violet hues. In Thelxiepeia, the grid is mostly regular, stretching across the horizontal length of the picture plane, undulating from more transparent squares to opaque stretches. The bottom right section lightens up, as if the squares gradually ran out of ink. Through the repeated lines, the canvas appears like a frieze of text, or a squared notebook waiting to be filled. Thelxiepeia is the most violet work, while Raidne lurches towards a duller mauve, with frequent passages that are heavily sanded over and thus flatter; the endpapers completely flush with the canvas. In Leucosia, the tones are closer to indigo, and the more heavily sanded sections appear luminous, as if the transparency of the endpapers allows light to pour in from behind. Leucosia is also the most fractious, with an uneven white strip cutting through the penultimate part of the canvas, be- 


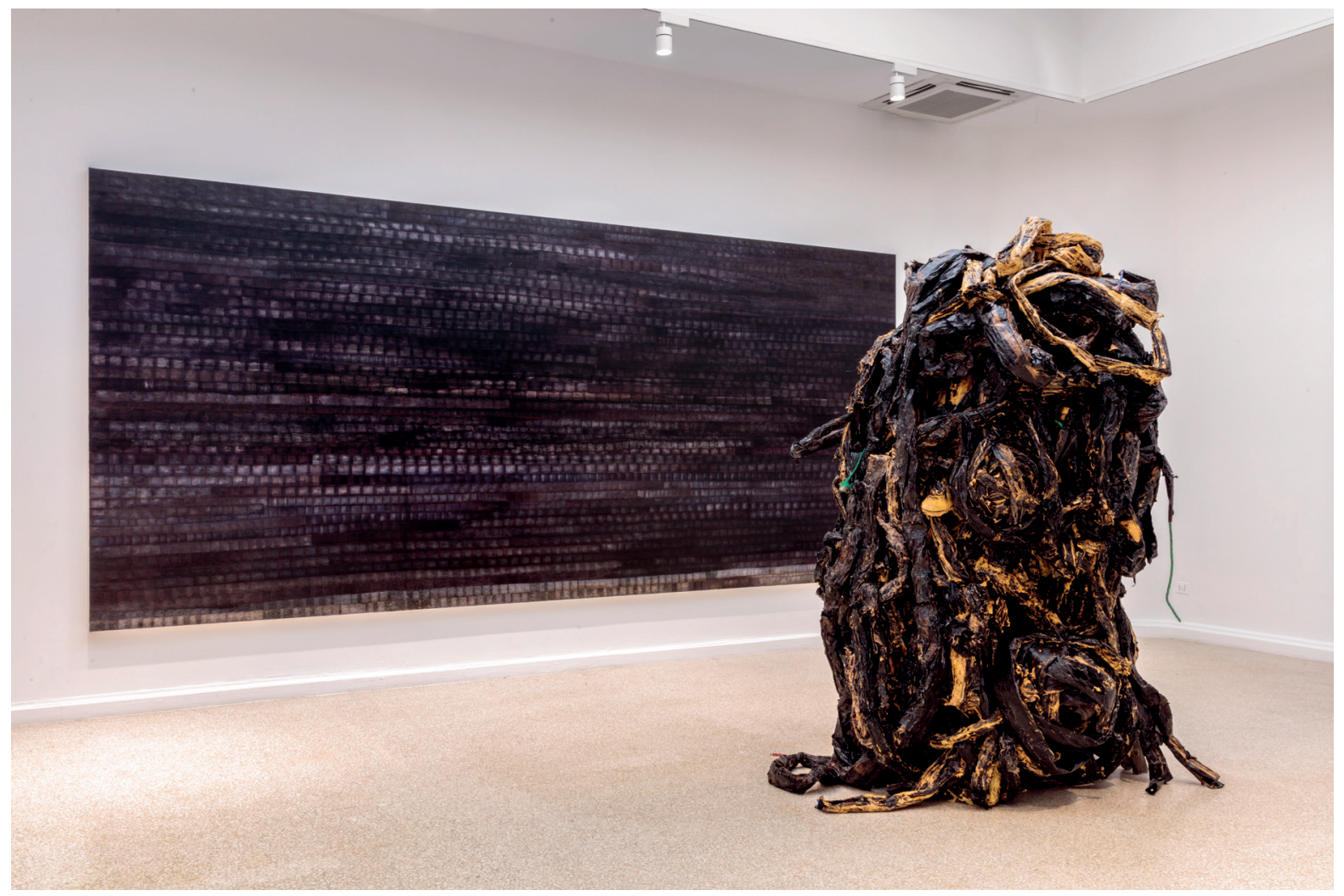

4 Installation view of Mark Bradford, Tomorrow Is Another Day. Venice, Biennale 2017, U.S. Pavilion Left to right: Thelxiepeia, 2016, mixed media on canvas, $243.8 \times 548.6 \mathrm{~cm}$; Medusa (cf. fig. 2)

fore one more line of unbroken endpapers meets the edge of the picture plane. Bradford describes how he "love[s] a cut that goes through matter. A painting is matter and the lines cut into it." ${ }^{19}$

Bradford's cut is the method by which his canvases put the sociality of their abstraction in high relief. The cut fractures and reveals what the grid rests upon: the materials that denote the social. As such, I see his cuts as akin to Fred Moten's reading of Billie Holiday's voice as a "cut" that stands as "unprecedented communication". ${ }^{20}$ As Moten writes, Holiday's "grained voice" cuts words: dividing, filling, cancelling and abounding them, with this "cut" as unprecedented communication standing as excessive, but illuminating. Moten pays particular attention to Holiday's recordings of her improvisations of the blues, addressing the relationship between improvisation and the "overdetermination of the recording and the determination of the blues as tragedy". ${ }^{21}$ Through this, Moten is concerned with the dynamic between singularity and totality, and in exploring Holiday's manipulation of the cut he draws on the Russian avant-garde director Sergei Eisenstein theorization and practice of overtonal montage. ${ }^{22}$ In Moten's discussion, these modes share a drive towards a "nonexclusive totality", a quality reminiscent of Bloch's arguments against Lukács' theorisation of totality as closed, rather than open. ${ }^{23}$

Eisenstein developed his theory of overtonal montage as part of his editing practice and outlined five types of montage: metric, rhythmic, tonal, overtonal and intellectual, with the order of these categories representing an ascent towards an ever-greater complexity. Overtonal montage is a combination of metric, rhythmic and tonal montage that produces the capacity 
for multiple associations, implications and consequences on behalf of the viewer, transcending the separation between those categories to produce a new totality. For Moten, what is at stake in the nonexclusive totality of Eisenstein's overtonal montage, and indeed Holiday's "cut", is "feeling" - a word he takes to denote a fleeting, contradictory proliferation of meaning that emerges through "opposition and relation of cut and suture". ${ }^{24}$ This "feeling" denotes that which cannot be contained, "an abundance that accrues especially at moments such as these when things sound 'edgy, maybe garbled at points', when 'ears literally burn with what the words don't manage to say"'. ${ }^{25}$ Something, as in Bradford's description of how the social "clings to the edges", is happening at the margins in the feeling evoked by Holiday's cut, spilling over, contradicting the whole, yet at the same time forming an organising principle.

As Annette Michelson explains, overtonal montage extends its principle to "all parameters susceptible to organization", ${ }^{26}$ and we can relate this to Bradford's statement that "the grid saved my life" because it formed a "safe, organized unit". ${ }^{27}$ Yet, like most modernist grids, Bradford's do much more than produce order and organisation. In Rosalind Krauss's analysis, the development and dominance of the grid within twentieth century art rested upon its "mythic power", which suggests "materialism (or sometimes science, or logic) [...] at the same time it provides us with a relief into belief (or illusion, or fiction)" ${ }^{28}$ The contradiction of the spiritual and the material within the grid was articulated in how artists such as Kazimir Malevich and Piet Mondrian saw the form as a "staircase to the universal", while it was also about nothing other than the collapse of the material and aesthetic planes of the painting's surface. ${ }^{29}$ In Krauss's argument, the grid's mythic status lies in the fact that it does not dissolve or resolve this contradiction, but rather covers over it, a quality that might be related to Bradford's finishing of

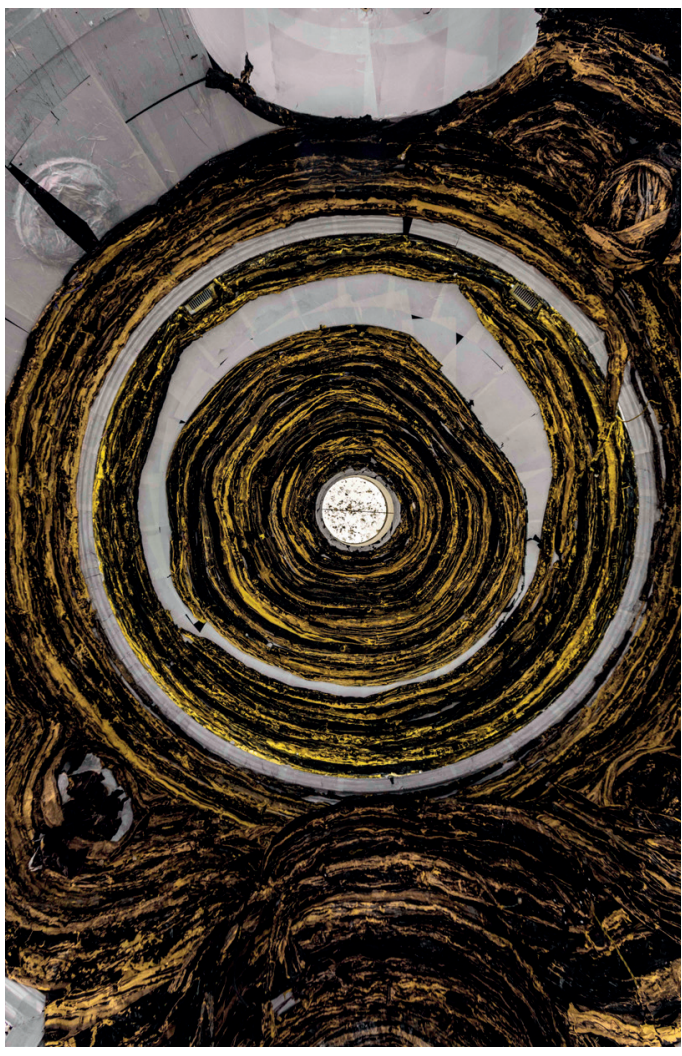

5 Installation view of Mark Bradford, Oracle (detail), 2017, mixed media on canvas, dimensions variable, part of: Mark Bradford, Tomorrow Is Another Day. Venice, Biennale 2017, U.S. Pavilion

the canvas with a sander to smooth out the surface. Yet, while smoothing out, Bradford's sanding simultaneously reveals the layers of the work, foregrounding the materiality of the endpapers and the sociality that contradicts the grid's flight into the realm of spirit.

Building upon Krauss's canonical reading, and writing about Martha Rosler's The Bowery in Two Inadequate Descriptive Systems (1974-1975), Steve Edwards develops what Krauss describes as a "centrifugal reading of the grid", that is, one which moves outwards and views the form as infinitely extendable and as compelling knowledge of the world beyond its bounds. ${ }^{30}$ In writing about Rosler's gridded series of twenty-one black and white photographs of the Bowery, which are paired with poetic snatches of text, Edwards 
suggests that the interchangeable and infinitely extendable qualities of the grid can be understood through Karl Marx's analysis of the fungible qualities of the commodity. ${ }^{31}$ However, this should not be taken to displace the 'spirit' side of the grid, but rather can be understood through those passages in Marx describing the 'wondrous', capricious and even fantastical quality of the commodity form..$^{32}$ In Edwards' analysis, we should understand the commodity as the root of the grid's mythic function, the idea that inspired this modernist trope. ${ }^{33}$ Yet, there's one more direction in which we can push the analysis of the grid, as it appears in Bradford's siren suite. Set within the American Pavilion, this proposal takes on another dimension, as the grid comes to suggest the history of the transatlantic slave trade.

The American Pavilion was opened in 1930 in the Giardini, designed by William Adams Delano and Chester Holmes Aldrich, 'gentleman architects' who modelled the building after Monticello, Thomas Jefferson's plantation in Charlottesville, Virginia. Jefferson's Monticello was inspired by Andrea Palladio's neoclassicism, which adhered to Roman architectural and design principles. In making visitors enter through the side door of the Pavilion, Bradford invokes the historically occluded slave quarters of Monticello, the passageways calling up what Frederick Douglass described as "the blood stained gate, the entrance to the hell of slavery" ${ }^{34}$ Here, inside the Monticello-like pavilion, the fungibility of the grid's component parts, built up through the endpapers in Bradford's siren suite, thus takes on new meaning. If the modernist grid, as Edwards suggests, denotes the fungibility of the commodity, the presence of this form within the Jeffersonian architecture of the American Pavilion should direct us towards thinking not only of coins or yards of linen, but of the enslaved as one of the foundational commodities for the growth and development of capitalism and the Atlantic world.
The entrance through the side door of the Pavilion is the most obvious way the visitor is directed towards reading the history of transatlantic slavery alongside the history of modernism. Yet, unlike the associative open totality of the room with the siren suite and Medusa, the shift of the entranceway leans heavily upon how art's social currency so often rests upon its capacity to invoke empathy. In Saidiya Hartman's discussion of the interplay between empathy, abolitionist campaigns to end slavery and the fungibility of the slave, she begins by recounting the 1837 letters of John Rankin to his brother who was a slaveholder. In these epistles, Rankin tries to persuade his brother of the evils of slavery by writing that his "flighty imagination" had allowed him to think of himself and his family as slaves, which in turn precipitated his empathy for those in bondage. Striving to produce a shared sense of horror through detailing the cruelty of "the lash" administered by a "morose and capricious master", but substituting the slave for himself and his family, Rankin employs this standard mode of empathetic identification to try and persuade his brother to heed the calls of abolitionists. ${ }^{35}$ Yet, as Hartman describes, Rankin actually "begins to feel for himself rather than for those whom this exercise in imagination is presumably designed to reach" ${ }^{36}$ This means the ease of Rankin's empathetic identification is "as much due to his good intentions and heartfelt opposition to slavery as to the fungibility of the captive body". ${ }^{37}$ As Hartman clarifies, "the fungibility of the commodity makes the captive body an abstract and empty vessel vulnerable to the projections of others' feelings, ideas, desires, and values". ${ }^{8}$

Bradford's recourse to the grid's mythic power within the neoclassical confines of the American pavilion, surrounding the disordered Medusa (which I will come onto in more detail shortly), mark out a dialectical tension where the whitewashed rotunda has always secreted the history of slavery, the sugar cubes of modernist referen-

Zeitschrift für Kunstgeschichte 81. Band/2018 


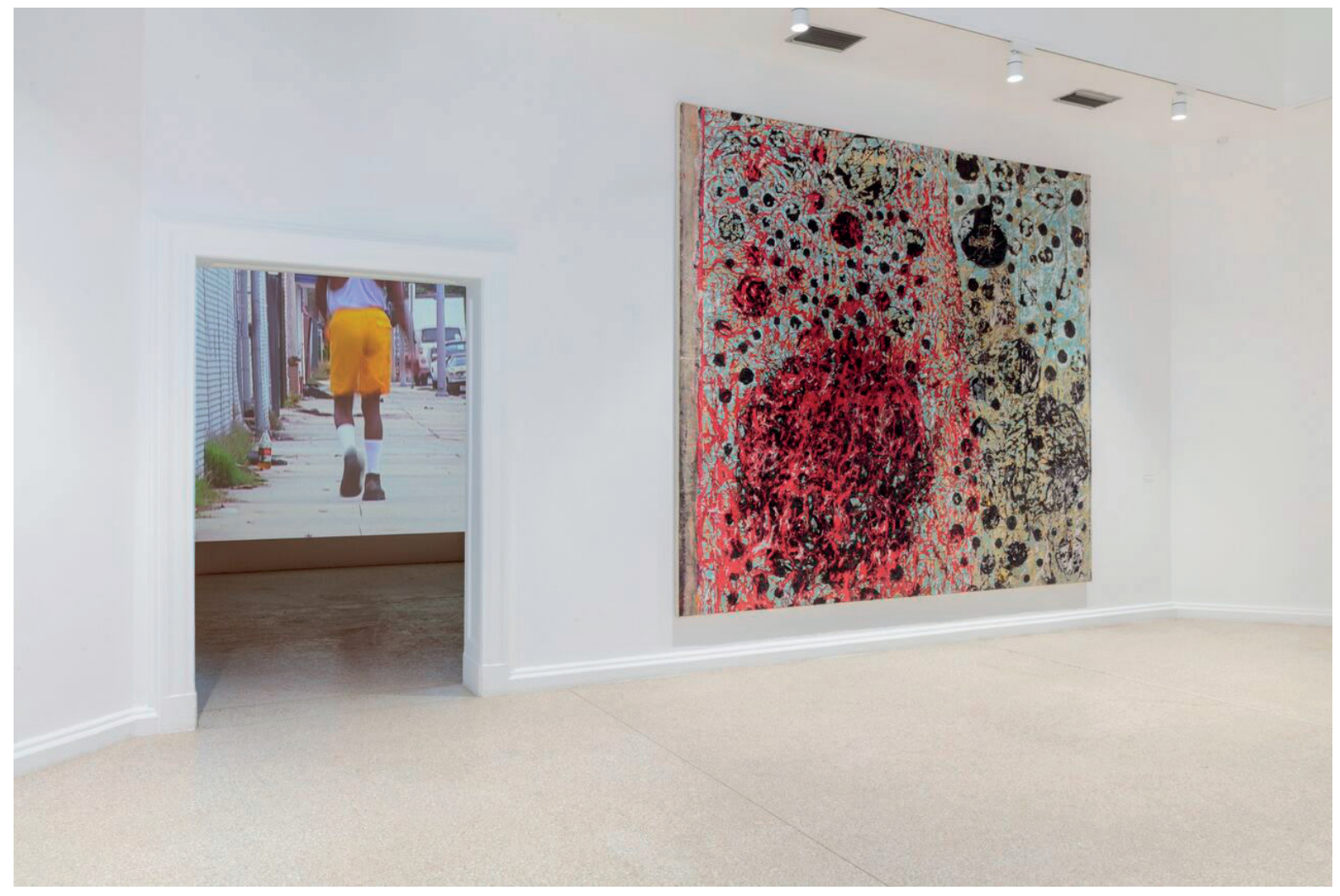

6 Installation view of Mark Bradford, Tomorrow Is Another Day. Venice, Biennale 2017, U.S. Pavilion Left to right: Niagara, 2005, video, colour, no sound, 3:17 min; 105194, 2016, mixed media on canvas, $322.6 \times 365.8 \mathrm{~cm}$

tiality always soaked in the blood of the plantation. Yet, as visitors enter the side door to the Monticello-like pavilion, informed by the brochure and the pavilion's attendants that this calls up the passages of slavery, this forms a trickier element within Bradford's exhibition, unfolding directly onto what Hartman describes as the "difficulty and slipperiness of empathy". ${ }^{9}$ What is at stake here is a mode of passage that calls up slavery as a distinct historical phenomenon one might vicariously imagine, almost as a form of performative historical re-enactment.

But of course these histories are ongoing. If not exceptional in the fact that the President is a white supremacist, recent U.S. history has brought the racial violence at the heart of American life to the fore yet again. On August $12^{\text {th }}$, 2017, anti-fascist demonstrators clashed with white supremacists that had assembled to pro- test the planned removal of the statue of Confederate General, Robert E. Lee from a public park in Charlottesville. In a short documentary, a woman made the following statement after a white supremacist ploughed his vehicle through the crowd, leaving one dead and many injured: "This is the face of supremacy. This is what we deal with everyday being African American. And this has always been the reality of Charlottesville. You can't stand in one corner of this city and not look at the master sitting on top of Monticello." ${ }^{40}$

This statement seeks to emphasise that the violence of white supremacy that was made so stark on that day is not the exception but the rule, a quality that also runs through the history of modernism, with the recent X-ray analysis of Kazimir Malevich's Black Square (1915) evidencing this so directly as to feel crude. The 
X-ray revealed an inscription referring to a racist joke authored by the writer and humourist Alphonse Allais in 1897, that captioned a black monochrome "Combat de nègres dans une cave pendant la nuit" ("Negroes fighting in a cave at night"). As the writer and artist Hannah Black describes, the rupturing moment of Malevich's Black Square is therefore at the same time a tawdry joke about "the illegibility of blackness". ${ }^{41}$ As Black elaborates, this means the painting that stands as an Ur-form for the artistic negation of narrative and representation, winds up back with representation, that is, the representation of the negation of certain subjects. ${ }^{42}$ While for Malevich, the square formed a "refuge" freeing art from "the dead weight of the real world", this "break for freedom (for art), this place of refuge (for the artist), is founded on or overlaid on top of black invisibility, itself unfree". ${ }^{43}$ This story about Malevich's black square, and Black's take on the matter, is not introduced here to delete the history of modernism because of its irrevocable racism, but rather to insist on not allowing the grid to once more cover over the paradox between spirit and materialism, social and abstraction, but instead to reckon with the force and meaning of its mythic status.

At best, this is what is at stake in Bradford's category of 'social abstraction'. However, along with that categorisation, his work is described in the pamphlet for the exhibition and on the website for the Pavilion, as renewing "the traditions of abstract and materialist painting". ${ }^{44}$ This statement invokes the term 'materialist painting' as if its meaning were self-evident, but it is not a familiar category. Perhaps these terms - social abstraction and materialist painting - function in order to clear a path for Bradford which lies far away from what has come to be described as "zombie formalism". This is a term coined by Walter Robinson in 2014, and designed to target what seems to be a revival, but really just signals the permanency of abstract painting as a cherished fixture of the post-1945 art market. ${ }^{45}$ How do the terms 'social abstraction' or 'materialist painting' act as critical and curatorial prophylactics against the possible criticism that Bradford's success lies in the decorative qualities abstract painting can assume? Contra a Lukácsean complaint about abstraction's lack of content, I see this fate of abstract painting - it's market success and so-called "zombie formalism" - as merely providing more evidence for the inherent sociality of abstraction because it lays bare the perpetual limit in how the art world calls up the 'social', the 'real' and the 'authentic' to designate marginality, poverty, and racial difference, stopping short of considering how the social world of the market is inseparable from the reproduction of such oppression. While Bradford's painting may call up the 'social' and 'materialism' through its choice of materials, the preceding discussion of the grid should direct us to considering how abstraction's claims of autonomy were always paradoxical.

\section{Form, Feeling, Reform}

This question of autonomy leads me onto another element of Bradford's work for the Venice Biennale 2017 that was not visible in the Pavilion, but has surely informed the critical legitimacy 'social abstraction' has gained as the adequate label for his practice. ${ }^{46}$ This is his collaboration with Rio Terà dei Pensieri, a cooperative organization that assists former prisoners and people under criminal judgment to (re)integrate into the workforce through training in primarily craft-based labour and services. A year prior to the opening of the Biennale, Bradford embarked on a six-year collaboration with the collective, which supports their aim of increasing employment and training opportunities for prisoners and ex-prisoners. A central facet of the collaboration so far has been Bradford's role in establishing a shop in Venice which sells soaps, bags, accessories and other goods made by prisoners, also providing 


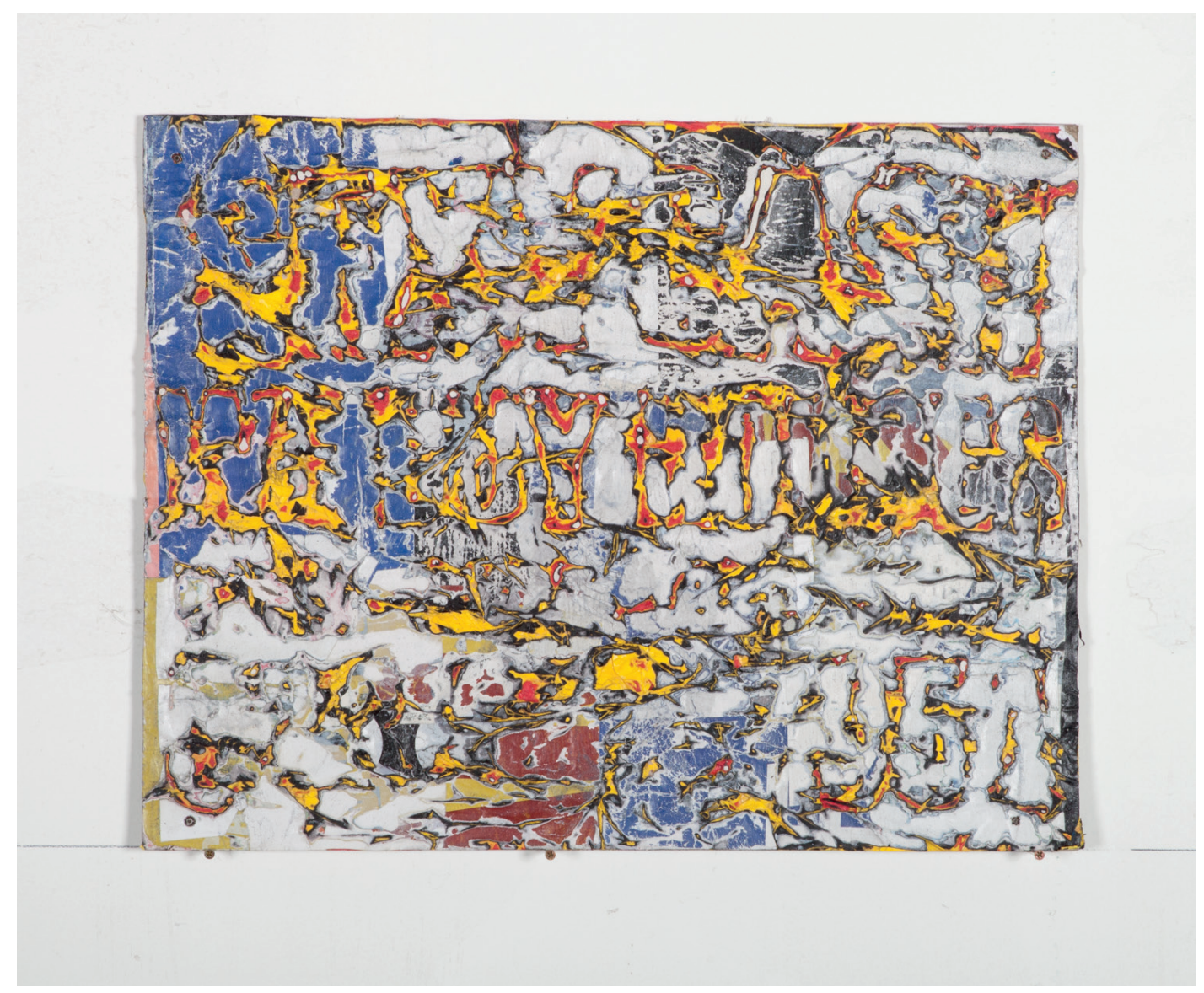

7 Mark Bradford, Sexy Cash Wall (detail), 2015, mixed media, $223.5 \times 1785.6 \mathrm{~cm}$

employment opportunities for people recently released. As the collective explains, the shop intends to function as a hub, providing information on services available in the city, including access to training, employment, housing and health services, with all sales proceeds going to projects that provide work for Rio Terà dei Pensieri inmates. ${ }^{47}$

Bradford funds this initiative himself and is also one of the main donors to Art + Practice (hereafter $\mathrm{A}+\mathrm{P}$ ), the organisation he founded in 2014 with his partner Allan DiCastro and the philanthropist and collector Eileen Harris Norton. A + P is based in the historically black neighbourhood of Leimert Park in Los Angeles and provides educational support services to foster youth, alongside free art exhibitions, lec- tures and talks. ${ }^{48}$ In Benjamin Buchloh's review of Bradford's work in the American Pavilion, he praises the artist's commitment to "proletarian audiences", a claim he validates through referring to his work with the Rio Terà dei Pensieri, and elaborates this through describing the artist's attention to materiality and urban space. ${ }^{49} \mathrm{It}$ is important to register that for Buchloh, Bradford achieves this precisely through his separation of his art practice from his activism. For Bradford does not situate his work with A $+\mathrm{P}$, or the Rio Terà dei Pensieri, as an artwork, rejecting the notion that this work falls within the genre of "social practice", meaning artworks that take engagement with social relations as their material. $^{50}$ Bradford's 'social abstraction' exists in a conceptually and qualitatively different realm 
from his work with $\mathrm{A}+\mathrm{P}$ and the Rio Terà dei Pensieri, with the latter two projects not considered as art by the artist. He simply acts as the conduit between these fields through his capacity to produce highly valuable objects, as well as through his access to wealthy donors, thus enabling a steady financial stream for the social projects. For Buchloh, Bradford's separation of the contradictory spheres of "art's function as the speculative investment of global surplus value (and occasional philanthropic generosity)" and its "extremely limited social and political efficacy" poses one current solution to the dissolution, fracturing and discontinuity that marks much contemporary art, qualities which in his article addressing the 2017 Venice Biennale, Buchloh associates most strongly with the work of Anne Imhof which appeared in the German Pavilion and won the Golden Lion for best national participation. ${ }^{51}$

While Buchloh's review situates Bradford's work as an "authentic record of the conditions of American urban public space" he describes Imhof's Faust as an authoritarian fusion of "cult and corporate design"..$^{2}$ Faust is a performance that ran intermittently through the Biennale and ranged from two to six hours in length. Set in a hard-edged steel and glass installation, a cage with roaming Doberman dogs inside stood at the exterior of the pavilion. Inside, the performers emerged subtly out of the crowd and initially moved together to a stirring soundtrack that then shifted from harsh bombast to a background drone as the work progressed. Dressed in the ubiquitous London/Berlin artist wear of the moment (1990s monochrome sportswear flecked with studio detritus, Reebok Classics, baseball cap, doodle-tattoos) the performers wrestled, lit fires, scurried underneath the floor into a crawl space, washed each other, yelled and hung precariously from a high ledge. Faust invoked authoritarianism, punishment, austerity, unsentimental sex, dirt and violence, performed in a largely affectless manner. The engagement between per- formers suggested a communitarian, Lord of the Flies style descent into brutality, punctuated by moments of austere tenderness (fig. 8).

If Bradford's work is marked by real commitment to "proletarian audiences", Buchloh views Imhof's communitarianism as merely a "youth cult", mired in the superficialities of fashion and "narcissistic delusion[s] of social redemption, of having escaped one more time, if only by a hair, from the vulgarity of daily life"..$^{3}$ Buchloh situates Imhof's relationship with her performers as inheriting Josef Beuys' fashioning of the artist as a cult leader, describing Faust as inheriting "this particular German lineage, from Wagner via Beuys to Imhof" that is marked by a commitment to "pretended or imaginary" bonds. ${ }^{54}$ For Buchloh, such bonds are always at risk of lurching towards the cultic, the authoritarian and the fascistic, incipiently striving towards a fantasy of communal wholeness rather than the more provisional, or improvised relationality he finds in Bradford's work. The chain of associations Buchloh establishes between Wagnerian spectacle, Beuysian communitarianism and Imhof's fusion of "cult and corporate design" demonstrates the continued presence of the interwar debates on the dynamic between communitarianism, fascism and expressionism within contemporary criticism..$^{55}$ Indeed, if Lukács's analysis of expressionism informed Buchloh's 1981 article Figures of authority, ciphers of regression on returns to representation in European painting, I see this as also haunting his assessment of Imhof. ${ }^{56}$ However, if Bradford's social abstraction is pitted against the authoritarian expressionism of Imhof, how are we to understand the former's recourse to formless skeins of rope, references to mythology, thickly layered shredded posters and the dissolving, destructive qualities of Oracle and Medusa? And how do we match this up with the commitment to proletarian audiences apparently evidenced in his work with Rio Terà dei Pensieri?

As the American Pavilion's co-curator Christopher Bedford states of Bradford, "I don't know 


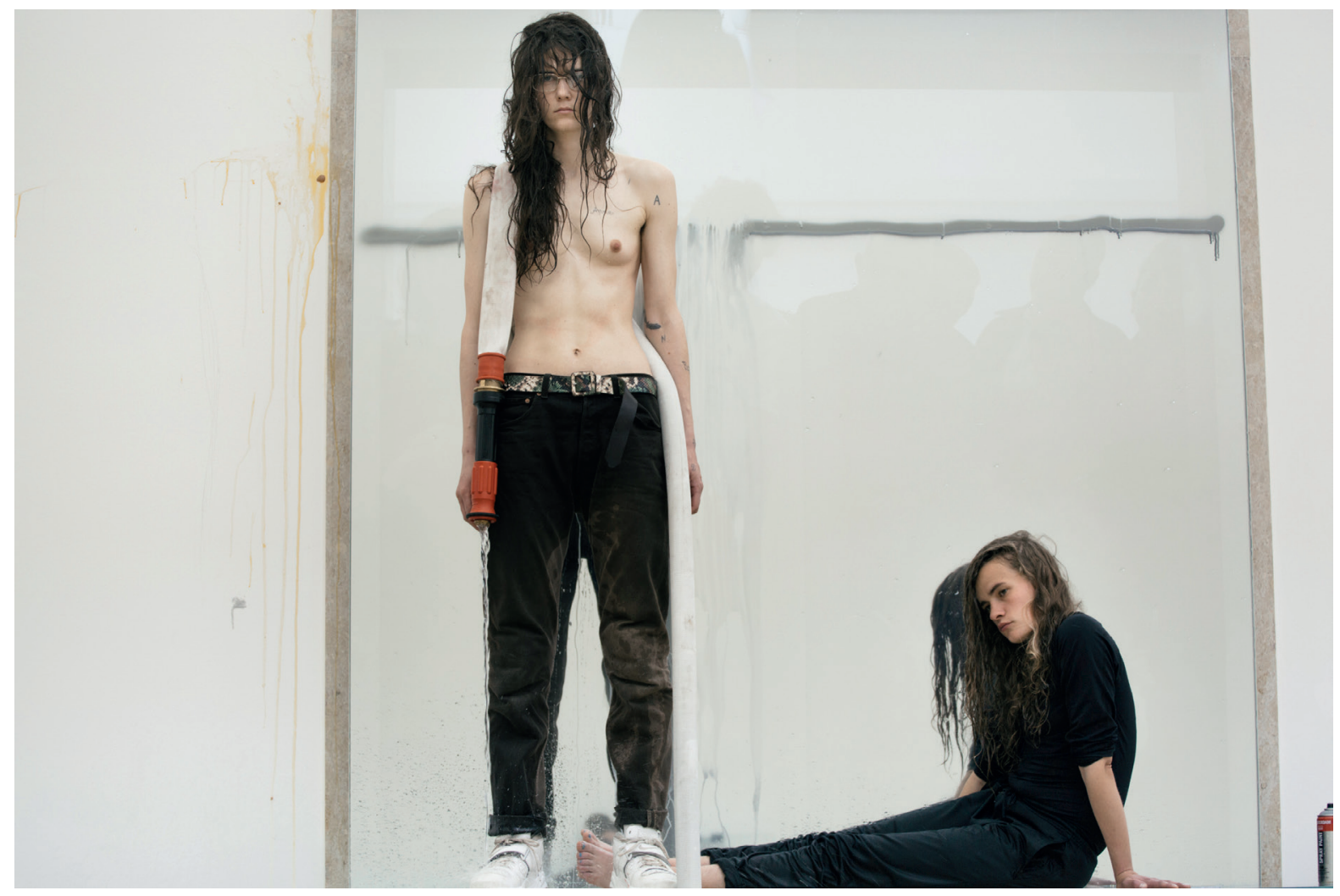

8 Eliza Douglas and Lea Welsch, part of: Anne Imhof, Faust, performance and installation. Venice, Biennale 2017, German Pavilion

if we've seen someone with the dexterity of De Kooning who is also committed to activism".57 Such comparisons with Abstract Expressionist painters are frequent within the reception of Bradford. Writing in artnet, Andrew Goldstein describes Bradford as "our Jackson Pollock" and more frequently, similarities with Clyfford Still have been suggested, particularly following a shared presentation of their work at the Denver Art Museum in $2017 . .^{58} \mathrm{I}$ am making a leap here, of course, from German figurative expressionism to the American school of abstract expressionism, but we know the two genres shared much in their recourse to the primitive and myths, as well as in their emphasis on individual expression. ${ }^{59}$ As Leon Golub wrote in 1955, "abstract expressionism wants a very good thing indeed - the intensity of personal commitment without the specificity such a view ordinarily entails". ${ }^{\circ}$ For Golub, the "direct impact" of a non-referential, "instinctual" expression upon the canvas simply worked to shore up the "reality of self" ${ }^{61}$ These criticisms - made during the height of abstract expressionism's hegemony within the American art world - feel very close to both Lukács's criticisms of expressionism, and the accusations Buchloh levels at Imhof. So unlike other contemporary critics, it is meaningful that Buchloh leapfrogs over de Kooning, Still or Pollock, and instead links Bradford with Eva Hesse and Agnes Martin, artists that stood beyond, or at the margins of abstract expressionism's heroics.

Because Bradford's work in the American Pavilion oscillates between integration and disintegration, wreckage and repair, this incorporates an expressionist investment in feeling and the irrational without this opening up a scale that inevitably slides from bohemianism to fascism. To borrow Raymond Williams' much-used phrase, the work's structure of feeling denotes "a 
kind of feeling and thinking which is indeed social and material, but [...] in an embryonic phase before it can become fully articulate and defined exchange". ${ }^{62}$ This also returns us to Moten's suggestion that what is at stake in the nonexclusive totality of the "cut" is "feeling", that is, a fleeting, contradictory proliferation of meaning, a quality I have argued shines through the siren suite's positioning in the American Pavilion. ${ }^{63}$ Feeling has often been related to formlessness within debates on expressionism, with critics disavowing this as seeking to excise mediation along the same lines as Golub's complaint that the vitalist qualities in abstract expressionist painting merely represents intensity without commitment or specificity. ${ }^{64}$ But Bradford presents feeling with form and specificity through his choice of materials and titles that combine the mythic with the prosaic. Through this, my claim is that we can locate a disordered, unbounded quality in his practice that works against expressionism's authoritarian and cynical strain, with its emphasis on feeling instead reaching towards invoking a mass or a hydra-like social form. Viewed from the violated interior of the American Pavilion, as most strongly expressed in Oracle's takeover of the central rotunda (fig. 5), the work might then be understood as seeking revenge against the systemic, dull brutality of national history, rather than only representing and recording a supposedly temporary spoiling of democracy under the U.S. President Donald Trump. ${ }^{65}$ This is, however, a very different proposition to the timelessness suggested by the Pavilion's curators, who suggest that Oracle "transports us back in time to the ancient grotto, a site between cave and altar, between nature and culture, where oracles would deliver profound truth and predictions". ${ }^{66}$ While this statement clearly works with myth as a structure that de-historicises and universalises, I see Bradford's American Pavilion as speaking directly to the material foundations of the United States as a settler colony and slave economy. But if I suggested that the invocation of empathy through the use of the Pavilion's side entrance compromises the political tone of such a project, Bradford's project with the Rio Terà dei Pensieri also sets limits.

\section{The Many-Headed Hydra}

As well as providing direct support to the Rio Terà dei Pensieri, Bradford's collaboration with the cooperative is also, as he stresses, an attempt to make visitors to the Pavilion reflect on the problems of the prison system, particularly in terms of its disproportionately repressive force within communities of colour. Yet the shortcomings of the project lie in its affirmation of the ideology of the criminal justice system as one that prioritises the inculcation of better work discipline among prisoners. The website for the project declares, "Prison work today has become a widespread reality that has spread to almost every region" before going on to explain that "even while incarcerated you can gain quality work experience" and "the opportunity to have small pockets of freedom, exchange, and satisfaction" ${ }^{67}$ But prison labour is still exploitation, even bonded labour because of the lack of a wage paid to most prisoners. How this constitutes a "small pocket of freedom" seems questionable, as little agency is given to prisoners within their choice to perform or not perform labour. This is of course a dynamic which is so severely racialised in the United States that it presents a direct continuity with the way that racial terror was integrated within the emergence and growth of capitalism from the antebellum era, through Jim Crow, to the contemporary prison industrial complex. ${ }^{68}$ Writing about Bradford's work with the Rio Terà dei Pensieri, as well as his involvement with $\mathrm{A}+\mathrm{P}$, Dan Fox suggests that under President Trump, "we need, more than ever, to be pragmatic and determined to push back at a government hell-bent on taking away from the socially marginalized and vulnerable 
their few state-subsidized safety nets and educational opportunities". ${ }^{69}$ I would suggest that the contemporary prison system and broader political landscape requires precisely not pragmatism but a mode of thinking and action that is much more intent on refusal, disorder and rebellion. The Rio Terà dei Pensieri unambiguously prioritises the idea that the route to a healthy life is through work, a notion that first emerged within the growth of capitalism and building of the Atlantic economy, but not without dispute.

In Peter Linebaugh and Marcus Rediker's The many-headed hydra, the authors describe how the classically educated architects of the emerging Atlantic economy situated the colonization of the New World as akin to the labours of Hercules. If Hercules had been the unifier of a centralized territorial state for the Greeks, and a symbol of imperialism for the Romans, the rulers of the emerging states, empires and economies of the Atlantic world saw Hercules' second labour, the slaying of the hydra, as particularly resonant with their goals. The myth of the manyheaded hydra formed a metaphor to describe the difficulties of maintaining discipline over the "motley crew" of dispossessed commoners, transported felons, indentured servants, religious radicals, pirates, urban laborers, soldiers, sailors and African slaves who formed the new labour force..$^{70}$ The hydra stood as a threatening emblem of disorder and resistance for the imperialist, Herculean ambitions of the emergent ruling class, with Linebaugh and Rediker's analysis seeking to uncover the histories where these disparate heads on this hydra cooperated against their rulers: through strikes, riots, mutinies, insurrections and revolutions. As they stress, "it would be a mistake to see the myth of Hercules and the hydra as merely an ornament of state, a classical trope in speeches, a decoration of ceremonial dress, or a mark of classical learning" ${ }^{71}$ The myth went much further in its material effects, as Francis Bacon and other intellectuals of the ruling class used it to produce a 'scientific' doctrine of monstrosity that justified violence and repression both at home and within the colonies. Bacon's doctrine drew upon classical antiquity, the Bible, and recent history to elaborate seven "multitudes" that deserved destruction: West Indians, Canaanites, pirates, land rovers, assassins, Amazons and Anabaptists. $^{72}$ In discussing these groups, Bacon took his terms from nature, including "swarms" and "shoals", and applied these to groups of people he saw as having degenerated from the laws of nature and taken "in their body and frame of estate a monstrosity". ${ }^{73}$ Bacon called for the study of monsters to understand these emerging multitudes, and to him, monsters formed one of the divisions of nature, which were: 1 ) nature in course; 2) nature wrought; and 3) nature erring, with these categories respectively denoting normality, artificiality, and monstrosity. Monstrosity was therefore pitted as straddling the natural and artificial, and emerged as essential to legitimising violent processes of experiment and control within the building of the Atlantic economy ${ }^{74}$

We see this discourse of monstrosity repeated in contemporary descriptions of people arriving from Africa, Asia and the Middle East into Europe as a "swarm", with this invective uttered by former British Prime Minister David Cameron in 2015, or in the British chancellor Philip Hammond's description of "marauding" Africans, or in the use of the term "clandestini" in the Italian press and by its politicians, a word that invokes illegality, priming the way for attacks by the farright, as well as criminalization by the state. ${ }^{75}$ Yet, just as the hydra resisted then, it does so today, even mobilising the monstrous. ${ }^{76}$ The conjoined and fungible quality of the hydra thus signal not only the brutality of capital but also the modes of struggle and defiance that continually emerge on ships and shop floors, in fields, prison cells, hostels and camps. This is how I see the disordered quality of myth in Bradford's America Pavilion working - therefore, in fact, working against the 
reformism of his project with the Rio Terà dei Pensieri - and I want to conclude with a closer discussion of Medusa to elaborate on this proposition.

Medusa is typically formless, in ways that the siren suite first appears typically formalist through its adherence to the grid. A roughly human sized and shaped tumble of black and yellow rope, caulk, paper and acrylic paint, the work's title as well as its form means that the sculpture appears ready to unfurl its knotted tendrils in an instant. Hair, as with the gridded endpapers in the siren suite, is invoked again, foregrounding the bodily as excessive and maybe even dangerous through the yellow and black warning colours of Medusa's locks. The sculpture unleashes a chain of associations, including Sigmund Freud's famous analysis of the myth as about the "terror of castration" through the association of Medusa's snake-hair with pubic hair, as well as her capacity to turn men to stone. ${ }^{77}$ Freud also connects Medusa's apotropaic powers with Rabelais' description of how "the devil took to flight when the woman showed him her vulva" ${ }^{8}$ This is an action that Hartman also finds in an oral history with the former slave Fannie Berry, recorded by the Works Progress Administration Federal Writers Project in Virginia in 1937. Berry described the behaviour of a fellow enslaved woman, Sukie, on the auction block, explaining how the slave traders ''zamined her an' pinched her an' den dey opened her mouf, an' stuck dey fingers in to see how her teeth was. Den Sukie got awful mad, and she pult up her dress an' tole de nigger traders to look an. see if dey could find any teef down dere". ${ }^{9}$

Here, the monstrous becomes powerful in ways that correspond with Hortense Spillers' argument that African American women - long excluded from the sphere of gender through the afterlives of how the middle passage turned humans into flesh - might gain the "insurgent ground" as a social subject through claiming monstrosity as a disavowal of both white- ness and gender. ${ }^{80}$ This is how I read the room with the siren suite surrounding Medusa. These works are borne through violence, but suggest the potential to turn history in another direction, forming an insurgent collective. That Bradford's work assumes the position of black femininity is also powerful when thinking through the materiality of these works; the endpapers denoting the social space of the hairdressers and the artist's place within that context as a gay man, the names of the sirens giving each canvas its title denoting a mythic feminine archetype that, like Medusa, render men incapacitated through their sexuality.

These myths - Medusa and the sirens - are of course connected to stereotypical fears and fantasies of black femininity as analysed by Spillers, standing particularly close to the "Sapphire" type, a dominant woman who usurps men's power. As Spillers explains, "Sapphire" sits alongside "Peaches", "Brown Sugar", "Earth Mother", "Aunty", "Granny", God's "Holy Fool”, a "Miss Ebony First", or "Black Woman at the Podium" as an ensemble of markers which form the "meeting ground of investments and privations in the national treasury of rhetorical wealth" ${ }^{81}$ Taking Daniel Moynihan's infamous 1965 report The negro family: The case for national action, which argued that "underachievement" by black males was the fault of black females, Spillers' analysis describes how "ethnicity" in Moynihan's report is situated as a mythical, dualistic and unchanging category, which enables the human body to become a resource for metaphor. ${ }^{82}$ Moving from her discussion of how slavery negated motherhood and kinship, thus meaning the black woman has been situated outside the traditional symbols of female gender, she argues "we are less interested in joining the ranks of gendered femaleness than gaining the insurgent ground as female social subject". ${ }^{8}$ By "claiming the monstrosity" Spillers suggests "Sapphire might rewrite after all a radically different text for female empowerment" ${ }^{84}$ 
While art's role is certainly limited in its capacity to challenge the social conditions of racism, mass incarceration and exploitation, its possibilities might still lie in its ability to step beyond reformist pragmatism and to invoke such modes of insurgency. This not only bears upon Bradford's work into the American Pavilion, but also has implications for understanding the limits of the artist's collaboration with Rio Terà dei Pensieri. Somewhat counter-intuitively, that project's adherence to the careful, rational logic of reform will always stand as an enclave-based endeavour, even more so than the bohemian indulgences Lukács found within expressionism's

1 For example, see Sean Coughlan, 'Monster' fatberg to go on display in museum, in: $B B C$ News, 12 December 2017, URL: https://www.bbc.com/news/educa tion-42324932 (date of last access 14 December 2017).

2 Georg Lukács, Expressionism: It's significance and decline [1934], in: idem, Essays on realism, ed. and trans. by Rodney Livingstone, Cambridge, Mass. 1981, 87.

3 Ibidem, 96. The emphasis is in the original.

4 Ibidem, 113.

5 For a short overview of the circumstances around this debate in relation to the Popular Front, see Ernst Bloch, Presentation I, in: Theodor W. Adorno, Walter Benjamin, Ernst Bloch, et al., Aesthetics and politics (Radical thinkers), London ${ }^{7} 2007,9-15$.

6 Ernst Bloch, Discussing Expressionism [1938], in: Adorno, Benjamin, Bloch, et al. 2007 (as note 5), 19.

7 Ibidem, 22.

8 Ibidem, 24.

9 Ernst Bloch, Heritage of our times [1935], trans. by Neville and Stephen Plaice, Cambridge 1991, 108.

10 Ibidem, 112.

11 Georg Lukács, Realism in the balance [1938], in: Adorno, Benjamin, Bloch, et al. 2007 (as note 5), 54.

12 Ibidem, 38.

13 Ibidem.

14 For an explanation of both authors' views of totality, see Martin Jay, Marxism and totality: The adventures of a concept from Lukács to Habermas, Berkeley 1986.

15 Mark Bradford quoted in Calvin Tomkins, What else can art do?, in: The New Yorker, 22 June 2015, URL: https://www.newyorker.com/magazine/2015/06/22/ what-else-can-art-do (date of last access 30 November 2017). abstraction and emphasis on feeling. The best elements within Bradford's Pavilion are not reparative or instructive - unlike the slippery empathy prompted by the entranceway - precisely because they are capable of denoting the middle passage as modernity's foundation, refusing to cleave the two apart. Where this works most powerfully, the two tonal registers of form and feeling consistently oscillate - meaning the cool grid of the siren suite is a modernist sugar cube drenched in blood, the disordered expressivity of Medusa a revolutionary subject who refuses a singularising heroism, and instead forms part of the hydra.
16 Holland Cotter, Art in review: Mark Bradford, in: The New York Times, 9 November 2001, URL: https://www. nytimes.com/2001/11/og/arts/art-in-review-markbradford.html (date of last access 22 August 2018).

17 Christopher Bedford and Mark Bradford, Like a loose shawl [interview], in: Katy Siegel and Christopher Bedford (eds.), Mark Bradford: Tomorrow is another day, New York/Berlin 2017, 94-127, here 113.

18 Ibidem, 118.

19 Katy Siegel, Biography of a painting, in: Siegel and Bedford 2017 (as note 17), 46-65, here 56.

20 Fred Moten, In the break: The aesthetics of the black radical tradition, Minneapolis 2003, 103.

21 Ibidem, 120.

22 Ibidem, $120-121$.

23 Ibidem, 121. Bloch writes that "Lukács's thought takes for granted a closed and integrated reality that does indeed exclude the subjectivity of idealism, but not the seamless 'totality' which has always thriven best in idealist systems, including those of classical German philosophy. Whether such a totality in fact constitutes reality, is open to question." Bloch 1938 (as note 6), 22.

24 Moten 2003 (as note 20), 122. The phrases "edgy, maybe garbled at points" and "ears literally burn with what the words don't manage to say" is quoted by Moten from Nathaniel Mackey, Bedouin Hornbook, Callaloo Fiction Series, vol. 2, Lexington 1986, 34.

25 Ibidem, 122.

26 Annette Michelson, Reading Eisenstein reading 'Capital', in: October 2, 1976, 26-38, here 30.

27 Bedford and Bradford 2017 (as note 17), 114.

28 Rosalind Krauss, Grids, in: October 9, 1979, 50-64, here 54.

29 Ibidem. 
30 Ibidem, 63 .

31 Steve Edwards, Martha Rosler: The Bowery in two inadequate descriptive systems, London 2012, 61.

32 Karl Marx, Capital: A critique of political economy, vol. 1 [1867], trans. by Ben Fowkes, London 1976, 63 .

33 This is also what led Lukács to deride the abstract qualities of expressionism, viewing this as merely correspondent with the circulation of money and its place as the most "extreme form of abstraction in the entire process of capitalist production", whereas realism formed a means of interrogation, and even a reparative response. See Lukács 1938 (as note 11), 38.

34 Frederick Douglass, Narrative of the life of Frederick Douglass: An American slave, in: Henry Louis Gates Jr. (ed.), The classic slave narratives, New York 1987, 255-332, here 259 .

35 John Rankin, quoted in: Saidiya Hartman, Scenes of subjection: Terror, slavery, and self-making in nineteenth century America, Oxford 1997, 18.

36 Ibidem, 18.

37 Ibidem, 19.

38 Ibidem, 21.

39 Ibidem, 18.

40 See Elle Reeve, Charlottesville: Race and terror, produced by Vice News, 14 August 2017, URL: https:// www.youtube.com/watch? $\mathrm{v}=\mathrm{RIrcB} 1 \mathrm{sAN} 8 \mathrm{I}$ (date of last access 19 December 2017).

41 Hannah Black, Fractal freedoms, in: Afterall: A Journal of Art, Context and Enquiry 41, 2016, 4-9, here 6.

42 Ibidem.

43 Ibidem.

44 See URL: https://www.markbradfordvenice2017.org/ exhibition/ (date of last access 22 August 2018).

45 Walter Robinson, Flipping and the rise of Zombie For malism, in: Artspace, 3 April 2014, URL: https://www. artspace.com/magazine/contributors/see_here/the rise_of_zombie_formalism-52184 (date of last access 22 August 2018).

46 The category is frequently cited by critics writing on Bradford's practice, see for example Tomkins 2015 (as note 15); Leon Hilton, In the flesh: Mark Bradford in the US Pavilion, in: Art in America, 19 May 2017, URL: https://www.artinamericamagazine.com/ news-features/news/in-the-flesh-mark-bradfordin-the-us-pavilion/ (date of last access 16 December 2017); Wendy Vogel, Reviews: Mark Bradford, in: Art in America, 27 January 2016, URL: https://www. artinamericamagazine.com/reviews/mark-bradford (date of last access 13 July 2018).

47 See URL: https://www.rioteradeipensieri.org/en/process-collettivo/ (date of last access 18 December 2017).

48 Before opening the project, Bradford, DiCastro and Norton gained support from the Hammer Museum in Los Angeles; the director Ann Philbin brought in funding from the James Irvine Foundation and established a two-year partnership whereby staff from the Hammer curated four exhibitions a year. Such partnerships enable $\mathrm{A}+\mathrm{P}$ to take out contracts with service providers such as First Place for Youth, an organisation that provides life-skills training, access to housing opportunities, education and employment support to foster youth living in Southern California. See Tomkins 2015 (as note 15$)$.

49 Benjamin H.D. Buchloh, Rock, paper, scissors, in: Artforum International 56, 2017, URL: https://www. artforum.com/print/201707/benjamin-h-d-buchlohon-some-means-and-ends-of-sculpture-at-venicemuenster-and-documenta-70461 (date of last access 22 August 2018), footnote 9.

50 See Katy Siegel and Christopher Bedford, Introduction, in: Siegel and Bedford 2017 (as note 17), 8-15, here 13; also Sarah Lewis, The art of productive dissent, in: ibidem, $66-81$, here 75 .

51 Buchloh 2017 (as note 49).

52 Ibidem.

53 Ibidem. This clearly echoes Lukács's 1934 claim that expressionism is marked by an "extraordinary poverty of content (which) stands in crying contrast to the pretension of its delivery, to the exaggerated and over-intense subjective emotionalism of its presentation”, Lukács 1934 (as note 2), 87.

54 Buchloh 2017 (as note 49).

55 Buchloh also describes Imhof's "cult of glass" as hovering between the utopian transparency of expressionist design by Bruno Taut and Ludwig Mies van der Rohe and "corporate architecture's fascistic, massive glass deployments, which pretend to offer universal transparency but actually enforce total secrecy and control." Buchloh 2017 (as note 49). In this sense, it seems one could read Imhof's Faust as encapsulating the aspirations, the limitations and the co-opting of expressionism, a feat which clearly warrants more exploration. Although developing this argument is beyond the scope of this article, I hope it nevertheless contributes to a broader discussion on the contemporary resonance of expressionist modes and their relation to historical precedents.

56 Benjamin H. D. Buchloh, Figures of authority, ciphers of regression: Notes on the return of representation in European painting, in: October 16, 1981, 39-68. In this article, he criticises neo-expressionists including Anselm Kiefer and George Baselitz as devoted to a "romanticization of exotic and primal experience" in which art was positioned as an esoteric retreat from the alienation and violence of capital.

57 Carolina A. Miranda, Mark Bradford brings 'dexterity of De Kooning' and a commitment to activism to 2017 Venice Biennale, in: Los Angeles Times, 21 April 2016, URL: https://www.latimes.com/entertainment/ arts/miranda/la-et-cam-0421-mark-bradford-venice-biennale-20160421-story.html (date of last access o7 December 2017). 
58 Andrew Goldstein, Mark Bradford is our Jackson Pollock, in: artnet, 11 May 2017, URL: news.artnet.com/ exhibitions/mark-bradford-is-our-jackson-pollockthoughts-on-his-stellar-u-s-pavilion-at-the-venicebiennale-957935 (date of last access 17 December 2017).

59 For an exploration of the social and political role of myth in Abstract Expressionism, see Michael Leja, Reframing abstract expressionism: Subjectivity and painting in the 1940s, New Haven/London 1993.

6o Leon Golub, A critique of abstract expressionism, in: College Art Journal 14, 1955, 142 - 147, here 146.

61 Ibidem, 143.

62 Raymond Williams, Marxism and Literature, Oxford $1977,131$.

63 Moten 2003 (as note 20), 122.

64 See for example Hal Foster, The expressive fallacy, in: idem (ed.), Recodings: Art, spectacle, cultural politics, Seattle $1985,59-78$, here 63 .

65 This is how a number of critics viewed Oracle, the spoiled, central rotunda of the Pavilion. See, for example, Mark Hudson, Strong art, but less spoonfeeding next time, please, in: The Telegraph, 12 May 2017, URL: https://www.telegraph.co.uk/art/what-tosee/less-spoon-feeding-next-time-please-venicebiennale-2017-review/ (date of last access 19 December 2017).

66 Inside Mark Bradford's US Pavilion at the Venice Biennale, in: Phaidon, May 2017, URL: uk.phaidon. com/agenda/art/articles/2017/may/1o/inside-markbradfords-us-pavilion-at-the-venice-biennale/ (date of last access 22 August 2018).

67 Rio Terà dei Pensieri and Mark Bradford: A collaboration, URL: https:/www.rioteradeipensieri.org/en/ process-collettivo (date of last access 22 August 2018).

68 Among the extensive literature on incarceration rates and the legacies of slavery, see Michelle Alexander, The new Jim Crow: Mass incarceration in the age of colorblindness, New York 2010, or Angela Davis, Are prison's obsolete?, New York 2003, for their detailed analysis of this logic.

69 Dan Fox, Sign of the times, in: Frieze, 29 April 2017, URL: frieze.com/article/signs-times-o (date of last access 21 December 2017).

70 Marcus Rediker and Peter Linebaugh, The manyheaded Hydra: The hidden history of the revolutionary Atlantic, London 2000, 4.

71 Ibidem, 6.

72 Bacon cited in ibidem, 39.

73 Ibidem.

74 Ibidem.
75 David Cameron criticised over migrant "swarm" language, $B B C$ News, 30 July 2015, URL: https://www.bbc. com/news/uk-politics-33716501 (date of last access 22 August 2018); Francis Perraudin, Marauding migrants threaten standard of living says Foreign Secretary, in: The Guardian, 10 August 2015, URL: https://www. theguardian.com/uk-news/2015/aug/og/africanmigrants-threaten-eu-standard-living-philip-hammond (date of last access 22 August 2018). 'Clandestini' is a favoured term of Matteo Salvini, the current Deputy Prime Minister and Minister of the Interior as well as leader of Italy's Lega Party, see Frederika Randall, Mattero Salvini's March on Rome, in The Nation, 12 June 2018, URL: https://www.thenation. com/article/matteo-salvinis-march-rome/ (date of last access 22 August 2018). For an account of the rise of far-right attacks on migrants in Italy within this climate, see Richard Brodie, Italy's new racist storm, in: Jacobin, 9 February 2018, URL: https://www.jacobinmag.com/2018/o2/italy-election-migrant-racismmacerata-attack (date of last access 22 August 2018).

76 To give an example of how the monstrous has been mobilized culturally in recent years, we could refer to the Ghanaian-Italian rapper Bello Figo, who mocks the Italian right-wing reaction to demands for WiFi and better food by asylum seekers stuck within the Italian hostel system, as well as stereotypes of black men's laziness and sexual voracity in records such as Bello Figo $\mathrm{ft}$. the GynoZz, I don't pay rent, URL: https://www.youtube.com/watch?v=ookGv44MMd4 (date of last access 22 August 2018). I first heard of Bello Figo via Richard Brodie, who situates his music in the context of struggles within the Italian hostel system, in: We are Plan C, Zero Boars \#3, 8 October 2017, URL: https://www.weareplanc.org/blog/zeroboats-3/ (date of last access 22 August 2018).

77 Sigmund Freud, Medusa's head [1940], in: Writings on art and literature, Stanford 1997, 264-265.

78 Ibidem.

79 Fannie Berry, cited in Hartman 1997 (as note 35), 46.

80 Hortense Spillers, Mama's baby, papa's maybe: An American grammar book, in: Diacritics 17, 1987, 6481 , here 81 .

81 Ibidem, 65 .

82 Ibidem, 66.

83 Ibidem, 8 o.

84 Ibidem. In Bradford's own account, he describes the rapper Lil' Kim as his Medusa, citing how she negotiated the machismo of rap music during the 1990s. See Bedford and Bradford 2017 (as note 17), 122.

Photo Credits: 1 - 6 Courtesy the artist and Hauser \& Wirth; photo: Josh White. -7 Courtesy the artist and Hauser \& Wirth. - 8 Courtesy: German Pavilion 2017, the artist; photo: Nadine Fraczkowski. 